\title{
The Necessity of Recycling of Waste Li-Ion Batteries Used in Electric Vehicles as Objects Posing a Threat to Human Health and the Environment
}

\author{
Agnieszka Sobianowska-Turek ${ }^{1}$, Weronika Urbańska ${ }^{1, * \mathbb{D}}$, Anna Janicka ${ }^{2}$ (D) Maciej Zawiślak ${ }^{2}$ \\ and Jędrzej Matla ${ }^{2}$ (D) \\ 1 Faculty of Environmental Engineering, Wrocław University of Science and Technology, Wybrzeże \\ Wyspiańskiego 27, 50-370 Wrocław, Poland; agnieszka.sobianowska-turek@pwr.edu.pl \\ 2 Faculty of Mechanical Engineering, Wrocław University of Science and Technology, Wybrzeże Wyspiańskiego \\ 27, 50-370 Wrocław, Poland; anna.janicka@pwr.edu.pl (A.J.); maciej.zawislak@pwr.edu.pl (M.Z.); \\ jedrzej.matla@pwr.edu.pl (J.M.) \\ * Correspondence: weronika.urbanska@pwr.edu.pl
}

\section{check for} updates

Citation: Sobianowska-Turek, A.; Urbańska, W.; Janicka, A.; Zawiślak, M.; Matla, J. The Necessity of Recycling of Waste Li-Ion Batteries Used in Electric Vehicles as Objects Posing a Threat to Human Health and the Environment. Recycling 2021, 6, 35. https://doi.org/10.3390/ recycling 6020035

Academic Editors: Sascha Nowak and Akira Otsuki

Received: 13 April 2021

Accepted: 29 May 2021

Published: 1 June 2021

Publisher's Note: MDPI stays neutral with regard to jurisdictional claims in published maps and institutional affiliations.

Copyright: (C) 2021 by the authors. Licensee MDPI, Basel, Switzerland. This article is an open access article distributed under the terms and conditions of the Creative Commons Attribution (CC BY) license (https:// creativecommons.org/licenses/by/ $4.0 /)$.

\begin{abstract}
The automotive industry is one of the fastest-growing sectors of the modern economy. Growing customer expectations, implementing solutions related to electromobility, and increasingly stringent legal restrictions in the field of environmental protection, determine the development and introduction of innovative technologies in the field of car production. To power the most modern vehicles that include electric and hybrid cars, packages of various types of lithium-ion cells are used, the number of which is constantly growing. After use, these batteries, due to their complex chemical composition, constitute hazardous waste that is difficult to manage and must be recycled in modern technological lines. The article presents the morphological characteristics of the currently used types of Li-ion cells, and the threats to the safety of people and the environment that may occur in the event of improper use of Li-ion batteries and accumulators have been identified and described on the basis of the Regulation of the European Parliament and Council (EC) No. 1272/2008 of 16 December 2008 and No. 1907/2006 of 18 December 2006 on the classification, labeling and packaging of substances and mixtures and the registration, evaluation, authorization and restriction of chemicals (REACH), establishing the European Chemicals Agency.
\end{abstract}

Keywords: Li-ion batteries; recycling of lithium-ion batteries; electric vehicles; electromobility; environmental protection

\section{Introduction}

The global demand for lithium-ion batteries (LIBs) intended for the automotive industry is growing steadily and rapidly, which is related to growing market interest in electric and hybrid vehicles. Currently, there are numerous configurations of electric vehicles in the commercial market, which can be divided as follows: battery electric vehicles (BEVs), plug-in hybrid electric vehicles (PHEVs), range-extended electric vehicles (REVs) and fuel-cell electric vehicles (FCEVs).

In 2014-2019, an increase in the number of registered electric vehicles from several hundred thousand to over two million has been observed [1]. This trend will continue, given that many European countries plan or are already implementing a ban on the registration of vehicles powered exclusively by a combustion engine (Table 1) [1].

This situation is determined by the policy and legislation limiting global carbon dioxide emissions, which affect the automotive market in each of its sectors. The climateneutral economy has become a priority not only for the long-term strategy of the European Union (2005) but also for the whole world [2]. Electromobility has become an extremely important concept for the development of the design of individual passenger vehicles, but 
also in mass transportation (including public transit) as evidenced by numerous support programs offered by the European Commission [3].

Table 1. List of European countries implementing the ban on registration of vehicles equipped with a combustion engine only, along with dates (own study based on [1]).

\begin{tabular}{cc}
\hline Year of Implementation & Country \\
\hline 2025 & Norway \\
\hline 2030 & Sweden, The Netherlands Ireland, Denmark \\
\hline 2032 & Scotland \\
\hline 2040 & France, the United Kingdom \\
\hline & Poland, Spain, Italy, Slovenia, Romania, \\
Declaring implementation in the coming years & $\begin{array}{c}\text { Hungary, Slovakia, Finland, Switzerland, } \\
\text { Germany, Austria, Belgium }\end{array}$ \\
&
\end{tabular}

Along with the trends in the global economy, the interest of scientists in issues related to the automotive industry is also growing dynamically. The latest research concepts concern mainly issues related to the methods of constructing autonomous vehicles based solely on electric drives, but also to the use, operation and recycling of the currently most commonly used batteries used to power electric and hybrid vehicles, i.e., lithium-ion batteries $[1,4]$. In the last two decades, the number of published articles related to LiBs has increased from several dozen to several thousand publications annually [1]. According to the international patent database, by the end of the last year, over 10,500 patents in this area were obtained. In addition to research on Li-ion batteries and their waste, new technological solutions in the construction and operation of batteries are constantly sought, e.g., the possibility of using batteries based on the lithium-metal anode. In the automotive industry, lithium-sulfur (Li-S) batteries, composed of graphene sulfur cathode and a lithium metal anode protected by a lithium-ion conductive layer are particularly promising, the technology of which is more sustainable and more environmentally friendly than conventional LiBs [5].

Electric vehicles are promoted as zero-emissions, more energy-efficient and easier to service than vehicles equipped with a combustion engine [6]. While they have several advantages in the form of a significant impact of greenhouse gas emissions decrease with simultaneous reduction of local emissions, it should not be forgotten that those vehicles are, however, responsible for non-exhaust air pollution caused by the road surface and brake system components wear. Besides, as outlined at the beginning of this article, with the introduction of electric vehicles on the market, some other environmental problems arise that require urgent attention from researchers. The growing demand for lithium-ion batteries is precisely one of those problems. As a result of global activities for electromobility, it is predicted that by 2030 the volume of LIBs sold will increase from approximately 200 to $1200 \mathrm{GWh}$ [1]. The increase will be related not only to the development of technology and the expansion of the cell capacity but also to placing on the market a growing load of rare metals and substances that are potentially dangerous for humans and the environment. The high demand for raw materials necessary for the production of new Li-ion cells will be associated with significant consumption of natural resources of various elements, which over time may lead to their depletion. Therefore, currently generated large amounts of waste batteries of this type should be subjected to material recycling, especially valuable and at the same time hazardous metals. Effective recycling of used batteries will allow for the recovery of individual components and their reuse, but also reduce the potential pollution of the environment with this type of waste.

This article presents a detailed and in-depth review of the literature to identify the potential dangers of using the increasingly popular lithium-ion batteries. Characteristics of the types of Li-ion accumulators most often used to power electric vehicles were presented, and the harmfulness of their chemical substances was assessed. As a result, it has been 
shown that Li-ion batteries are composed of many complex chemical substances that are potentially harmful to the environment and human health. These components are also contained in spent batteries of this type, so proper recycling is one of the most important tasks for modern, innovative waste management systems.

\section{General Characteristics of Li-Ion Batteries}

A lithium-ion battery, also called a secondary battery, a second-type battery, or an electric accumulator is a chemical source of current that can be repeatedly used and charged with electric current. There are two work cycles in accumulators: (1) charging-the cell is a receiver of electrical energy, which is converted into chemical energy, (2) energy consumption from the cell-during operation, the cell becomes a source of electric current due to the conversion of chemical energy into electrical energy; as a result of energy consumption, the battery is gradually discharged [7]. The basic elements involved in the process of generating electrical energy are the cathode (positive electrode) and the anode (negative electrode) impregnated in a liquid electrolyte having the ability to conduct lithium ions. Graphite or other types of carbon are most frequently used to build the anode. The large differences in charge and size between $\mathrm{Li}^{+}$and $\mathrm{Co}^{3+}$ ions lead to good cation ordering, which is crucial to ensure fast two-dimensional lithium-ion diffusion and conductivity in the lithium plane. The lithium-ion conduction in the lithium plane occurs from one octahedral site to the other through the adjacent tetrahedral void that shares the walls with the three octahedrons in the lithium layer because it provides the lowest energy barrier. With good cation ordering, the direct $\mathrm{Co}-\mathrm{Co}$ interaction at the common octahedral edges in the cobalt plane also facilitates good electronic conductivity. The good structural stability together with high electrical and lithium-ion conductivity provides fast charge and discharge characteristics with good reversibility [8]. This is one of the basic features of cobalt-containing lithium-ion batteries, making their efficiency relatively high concerning their size and weight. The chemical composition of lithium-ion cells depends primarily on the type of battery and the manufacturer. To ensure proper operation of the Li-ion battery, apart from the electrodes and the electrolyte, other components are also necessary for its structure. The cathode materials are comprised of metals such as cobalt, nickel and manganese in the crystal structure forming a multimetal oxide material to which lithium is added with aluminum foil as a collector. The vast majority of lithium-ion batteries use graphite powder as an anode material with copper foil as a collector. An important component of the accumulator is a binder, the function of which is to increase the adhesion between the anode or cathode material and the collector foil. An example of a compound that is widely used in cathodes for this purpose is polyvinylidene fluoride. The PVDF polymer is characterized by high stability and chemical resistance. The whole cell is enclosed in a plastic housing $[9,10]$.

Lithium-ion batteries are generally classified according to the cathode material. There are lithium-ion accumulators with a cathode made of lithium and cobalt oxide $\mathrm{LiCoO}_{2}$ (abbreviated as LCO), manganese oxide $\mathrm{LiMn}_{2} \mathrm{O}_{4}(\mathrm{LMO})$, lithium-manganese-cobalt oxide $\mathrm{LiNiMnCoO}_{2}$ (NMC), lithium-nickel-aluminum-cobalt oxide $\mathrm{LiNiCoAlO}_{2}$ (NCA) or a cathode made of iron phosphate $\mathrm{LiFePO}_{4}$ (LFP). The first commercial lithium-iron accumulators were installed in Sony cameras (1991), where a cathode made of lithium and cobalt oxide$\mathrm{LiCoO}_{2}$ was used. Over time, the carbon electrode made of porous coke was replaced with graphite. The LCO cathode has a layered structure. The high specific energy of LCO batteries makes a cell with a lithium cobalt oxide cathode a popular choice for mobile phones, laptops and digital cameras. The drawback of the LCO accumulator is its relatively short life span, low thermal stability and limited load capabilities (specific energy).

The lithium-ion cathode with manganese spinel was first introduced in 1983, and in 1996 Moli Energy commercialized the lithium-ion cell with manganese-lithium oxide $\left(\mathrm{LiMn}_{2} \mathrm{O}_{4}\right)$ as the cathode material. The architecture forms a three-dimensional spinel structure that improves the ion flow on the electrode, resulting in lower internal resistance and better current distribution. Another advantage of spinel is high thermal stability and 
enhanced safety, but the "life cycle" of the accumulator is limited. Low cell resistance allows for fast charging and high-current discharging in a suitable package the $\mathrm{LiMn}_{2} \mathrm{O}_{4}$ accumulator can be discharged at currents of 20.0-30.0 A with moderate heat build-up (18,650 packages with a typical $0.7-1.0 \mathrm{C}$ charge and 1.0 C discharge rate) [11]. The LMO cell is used for power tools, medical instruments and hybrid and electric vehicles.

One of the most successful lithium-ion battery systems is the cathodic combination of lithium-cobalt-nickel-manganese oxide (NMC). In a 18,650 package (cell dimensions $18.0 \mathrm{~mm}$ in diameter and $65.0 \mathrm{~mm}$ in length) for moderate load, NMC has a capacity of approximately $2800 \mathrm{mAh}$ and can supply from 4.0 to 5.0 A. NMC in the same cell optimized for a given power has a capacity of only about $2000 \mathrm{mAh}$ but supplies a continuous current of $20.0 \mathrm{~A}$. With a silicon-based anode, the cell will have a capacity of up to $4000 \mathrm{mAh}$ and more, but with a reduced load and a shorter life cycle. The silicon added to the graphite causes the anode to expand and shrink during the charge and discharge, making the cell mechanically unstable. The advantages of NMC accumulator are due to the combination of nickel and manganese. Nickel is known for its high specific energy, but relatively poor stability. In contrast, manganese forms a spinel structure to achieve low internal resistance but is characterized by low specific energy. Combining the two metals increases their advantages. The cathode usually consists of one-third nickel, one-third manganese and one-third cobalt, the composition is described as 1:1:1. The use of such a composition affects the reduction of the raw material costs due to the decrease in the amount of cobalt Another successful combination is the cathode consisting of five parts nickel, three parts cobalt and two parts manganese (5:3:2). With the constant technological progress, the share of nickel in NMC batteries is evolving - the next combinations of nickel, cobalt and manganese ratios are 6:2:2 and 8:1:1. Accumulator manufacturers are departing from the cobalt-rich systems, replacing them with nickel cathodes due to the high cost of cobalt. Nickel-based systems are characterized by a higher energy density, a lower cost and a longer cell life cycle compared to the accumulators based on cobalt cathodes, achieving a slightly lower voltage. NMC accumulators are used in power tools, e-bikes and other electric powertrains.

The cell with a lithium-nickel-cobalt-aluminum oxide cathode (NCA) has been around since 1999 and has been used for special applications, including medical devices. The properties of the NCA accumulator are similar to those of NMC cells; it is characterized by high specific energy, reasonably high specific power and a long life span.

In 1996, scientists at the University of Texas used phosphates as the cathode material for lithium-ion batteries. The phosphate system provides good electrochemical properties with low resistance, which is made possible with nano-scale cathode material. The most important advantages are the long life cycle, very good thermal stability and higher resistance of the cell in full charge conditions or if operating at high voltage for a prolonged time. LFP is often used to replace the lead-acid starter accumulator. Four connected lithiumphosphate cells produce $12.80 \mathrm{~V}$ current, similarly to six $2.0 \mathrm{~V}$ lead-acid cells connected in series. Time will tell if the $\mathrm{LiFePO}_{4}$ accumulator will replace classic lead-acid systems in vehicles as low temperature reduces the efficiency of lithium-ion systems, which can affect starting capacity in extreme cases.

$\mathrm{Li}_{4} \mathrm{Ti}_{5} \mathrm{O}_{12}$ cells are accumulators that have been known since the 1980s. They differ from other lithium-ion batteries in the structure of the anode, which is made of a lithium and titanium compound. The cathode, on the other hand, can be made of LMO or NMC. The LTO accumulator is safe, has excellent discharge properties in low temperatures and achieves $80 \%$ efficiency at $-30^{\circ} \mathrm{C}$. Thermal stability in high temperatures is also better than in other lithium-ion systems; however, this type of accumulator is expensive. Typical applications for this type of cell are electric powertrains, UPS units and solar-powered street lighting. 


\section{Characteristics of Li-Ion Batteries Used in Electric Vehicles}

Lithium-ion cell packages powering electric vehicles (EVs) typically are made of accumulator modules and a battery management system. The accumulator modules themselves consist of cells that are connected in series and/or in parallel. A single Li-ion battery (LIB) consists of four basic elements: anode, cathode, electrolyte and housing. The cathode materials in commercial LIBs are commonly lithium metal oxide or lithium metal phosphates as indicated in Section 2. Carbon materials, such as graphite and hard carbons, are used as the anode components [12]. The chemical compositions of individual types of lithium-ion batteries and an overview of the advantages and disadvantages of electrode materials used in commercial LIBs are presented in Tables 2 and 3.

Table 2. The chemical composition of individual lithium-ion batteries, based on [12].

\begin{tabular}{ccccc}
\hline Material & $\begin{array}{c}\text { LCO } \\
\text { \% Weight }\end{array}$ & $\begin{array}{c}\text { LFP } \\
\text { \% Weight }\end{array}$ & $\begin{array}{c}\text { LMO } \\
\text { \% Weight }\end{array}$ & $\begin{array}{c}\text { NMC } \\
\text { \% Weight }\end{array}$ \\
\hline Aluminum & 5.20 & 6.50 & 21.70 & 22.72 \\
Cobalt & 17.30 & - & - & 8.45 \\
Copper & 7.30 & 8.20 & 13.50 & 16.60 \\
Iron/Steel & 16.50 & 43.20 & 0.10 & 8.79 \\
Lithium & 2.00 & 1.20 & 1.40 & 1.28 \\
Manganese & - & - & 10.70 & 5.86 \\
Nickel & 1.20 & - & - & 14.84 \\
Binder & 2.40 & 0.90 & 3.70 & 1.39 \\
Electrolyte & 14.00 & 14.90 & 11.80 & 11.66 \\
Plastic & 4.80 & 4.40 & 4.50 & 3.29 \\
\hline
\end{tabular}

Table 3. Advantages and disadvantages of electrode materials used in lithium-ion batteries, based on [12].

\begin{tabular}{|c|c|c|c|c|c|}
\hline $\begin{array}{l}\text { Electrode } \\
\text { Material }\end{array}$ & $\begin{array}{l}\text { Voltage vs. } \\
\mathrm{Li} / \mathrm{Li}^{+}\end{array}$ & $\begin{array}{l}\text { Specific } \\
\text { Capacity } \\
\text { MAh/g }\end{array}$ & $\begin{array}{l}\text { Volumetric } \\
\text { Capacity } \\
\text { MAh } / \mathrm{cm}^{3}\end{array}$ & Advantages & Disadvantages \\
\hline $\mathrm{LCO}$ & 3.8 & 145 & 550 & $\begin{array}{ll}- & \text { high conductivity } \\
\text { - } & \text { high efficiency }\end{array}$ & expensive and harmful Co \\
\hline LFP & 3.4 & 170 & 589 & $\begin{array}{ll}- & \text { low price } \\
- & \text { environmentally friendly } \\
- & \text { long life cycle } \\
- & \text { high efficiency }\end{array}$ & $\begin{array}{l}\text { - low voltage and current } \\
\text { density } \\
\text { - } \quad \text { low concentration of } \mathrm{Li}^{+}\end{array}$ \\
\hline $\mathrm{LMO}$ & 4.1 & 120 & 596 & $\begin{array}{ll}- & \text { low price } \\
- & \text { environmentally friendly } \\
- & \text { high concentration of } \\
& \text { lithium } \\
- & \text { high conductivity }\end{array}$ & $\begin{array}{ll}- & \text { short life spans } \\
- & \text { small capacity } \\
- & \text { loss of capacity } \\
- & >55^{\circ} \mathrm{C}\end{array}$ \\
\hline NMC & 3.7 & 170 & 600 & $\begin{array}{ll}\text { - } & \text { high voltage } \\
\text { - } & \text { safer than the LCO cell }\end{array}$ & $\begin{array}{ll}- & \text { high price } \\
\text { - } & \text { expensive and harmful Co } \\
\text { and Ni } \\
\text { - } \quad \text { the cell requires voltage } \\
\text { "protection" and balancing }\end{array}$ \\
\hline
\end{tabular}

The anode and cathode material is bonded to the current-collecting sheets, i.e., $\mathrm{Cu}$ and $\mathrm{Al}$, with a binder such as polyvinylidene fluoride (PVDF). There are different electrolytes of Li-ion batteries, including liquid electrolytes and polymer electrolytes. Liquid electrolytes are used successfully in various accumulator applications. They consist of lithium salts $\left(\mathrm{LiPF}_{6}, \mathrm{LiBF}_{4}\right.$ and $\left.\mathrm{LiClO}_{4}\right)$ dissolved in one or a combination of several organic solvents, e.g., ethylene carbonate (EC), propylene carbonate (PC) and dimethyl sulfoxide (DMSO) [12]. 


\section{Li-Ion Cell as an Object Posing a Threat to Human Safety and the Environment}

Li-ion batteries, due to the content of various chemical substances in their composition, may pose a direct threat to the environment and human safety, e.g., in case of improper use. Depending on the electrode materials applied (cathode and anode) and the electrolyte, there are different types of hazards that, to various degrees, pose a risk to humans and the environment. The information necessary to identify the hazards can be found in the relevant legal acts-in the EU the binding legislation in this area is Regulation of the European Parliament and the Council (EC) No. 1272/2008 of 16 December 2008 on the classification, labeling and packaging of substances and mixtures, amending and repealing Directives 67/548/EEC and 1999/45/EC, and amending Regulation (EC) No. 1907/2006 [13]. In addition, the physicochemical and toxic properties of chemical substances are presented in detail in the chemical safety data sheets of the individual chemical compounds in the raw material composition of Li-ion cells. These data sheets are created in compliance with applicable laws (for the EU member states it is Regulation of the European Parliament and of the Council (EC) No. 1907/2006 of 18 December 2006 concerning the registration, evaluation, authorization and restriction of chemicals (REACH), establishing a European Chemicals Agency [14]) and contain information on the identification of hazards related to working with a chemical substance, the chemical composition of the compound in use, the physicochemical properties of the chemical compound and first-aid measures to be applied when exposed to chemicals. The chemical safety data sheets also include information on how to proceed in the event of fire (extinguishing agents, special hazards related to the substance or mixture and information for the fire service), unintended release to the environment (individual precautions, protective equipment and emergency procedures, precautions regarding environmental protection, methods and materials preventing the spread of contamination and used for contamination removal) and precautions for safe handling, conditions for safe storage, including information related to any mutual incompatibilities. An analysis of the documents in question makes it possible to prepare for exposure control and personal protective measures (control parameters: technical measures, individual protection measures and environmental exposure control), stability and reactivity (reactivity, chemical stability, a possibility of hazardous chemical reactions, conditions to be avoided and hazardous decomposition products), toxicity (toxicological effects) and environmental performance (toxicity, persistence and degradability, bioaccumulation potential, mobility in soil, results of PBT and $\mathrm{vPvB}$ activity and other adverse effects). Another important type of information is related to waste handling, transport (land transport-ADR/RID, inland waterway transport-ADN, air transport-IATA and sea transport-IMDG) and legislation on safety, health and environmental protection specific to substances and mixtures, chemical safety assessment.

In Li-ion batteries, the most frequently used cathode material is a compound in the form of $\mathrm{LiNiMnCoO}_{2}(\mathrm{NMC})$, which can cause an allergic skin reaction and has carcinogenic properties. The cathode compound used in LCO batteries has similar properties. In contrast, cathode materials of LFP and LMO batteries are not classified as hazardous compounds. Graphite, which is the anode of Li-ion cells, is not a harmful material. Table 4 presents detailed properties of the most popular electrode materials used in Li-ion cells along with the identification of possible threats. 
Table 4. An example composition of electrode materials in Li-ion batteries, with hazard identification, following Regulation of the European Parliament and of the Council (EC) No. 1272/2008 of 16 December 2008 on the classification, labeling and packaging of substances and mixtures [13].

\begin{tabular}{|c|c|c|c|}
\hline \multirow{2}{*}{ Chemical Compound } & \multirow{2}{*}{ CAS No. } & \multicolumn{2}{|l|}{ Hazard Identification } \\
\hline & & $\mathbf{A}^{*}, * *, * *$ & Category \\
\hline $\mathrm{LiCoO}_{2}$ & $12190-79-3$ & may cause an allergic skin reaction & H315 \\
\hline $\mathrm{LiNi}_{0.33} \mathrm{Mn}_{0.33} \mathrm{Co}_{0.33} \mathrm{O}_{2}$ & $346417-97-8$ & - $\quad$ carcinogenicity & H317 \\
\hline $\mathrm{LiMn}_{2} \mathrm{O}_{4}$ & 12057-17-09 & is not a hazardous substance or mixture according to & \\
\hline $\mathrm{LiFePO}_{4}$ & 15365-14-7 & Regulation of the European Parliament and the & - \\
\hline graphite & $7782-42-5$ & Council (EC) No. 1272/2008 & \\
\hline
\end{tabular}

*-Regulation of the European Parliament and the Council (EC) No. 1272/2008 of 16 December 2008 on the classification, labeling and packaging of substances and mixtures, amending and repealing Directives 67/548/EEC and 1999/45/EC and amending Regulation (EC) No. 1907/2006 [13]. **-Safety data sheets of chemical compounds prepared in compliance with Regulation of the European Parliament and of the Council (EC) No. 1907/2006 of 18 December 2006 concerning the registration, evaluation, authorization and restriction of chemicals (REACH), establishing a European Chemicals Agency, amending Directive 1999/45/EC and repealing Council Regulation (EEC) No. 793/93 and Commission Regulation (EC) No. 1488/94 and Council Directive 76/769/EEC and Commission Directives 91/155/EEC, 93/67/EEC, 93/105/EC and 2000/21/EC (as amended) [14], available on the websites of companies selling chemical substances [15-19]. ***-ECHA European Chemicals Agency [20].

Lithium-ion cells, in addition to electrode materials, also contain an organic electrolyte, usually in the form of lithium salts dissolved in a mixture of organic solvents. The most commonly used lithium salts are $\mathrm{LiPF}_{6}, \mathrm{LiBF}_{4}$ and $\mathrm{LiClO}_{4}$. $\mathrm{LiPF}_{6}$ compounds, which exhibit hazardous properties, mainly flammability and harmful effects to organs and tissues. The hazards of frequently used organic solvents, e.g., $\mathrm{C}_{3} \mathrm{H}_{4} \mathrm{O}_{3}, \mathrm{C}_{4} \mathrm{H}_{6} \mathrm{O}_{3}$ and $\left(\mathrm{CH}_{3} \mathrm{O}\right)_{2} \mathrm{CO}$, exhibit similar features. Examples of compounds included in the electrolyte used in $\mathrm{Li}$-ion batteries, along with hazard identification, are presented in Table 5.

Table 5. An example composition of electrolyte used in Li-ion batteries, with hazard identification, following Regulation of the European Parliament and of the Council (EC) No. 1272/2008 of 16 December 2008 on the classification, labeling and packaging of substances and mixtures [13].

\begin{tabular}{|c|c|c|c|}
\hline \multirow{2}{*}{ Chemical Compound } & \multirow{2}{*}{ CAS No. } & \multicolumn{2}{|l|}{ Hazard Identification } \\
\hline & & $\mathrm{A} * * * * * *$ & Category \\
\hline \multicolumn{4}{|c|}{ Lithium Salts } \\
\hline $\begin{array}{l}\qquad \mathrm{LiPF}_{6} \\
\text { Lithium hexafluorophosphate }\end{array}$ & $21324-40-3$ & $\begin{array}{ll}- & \text { harmful if swallowed } \\
- & \text { causes skin irritation } \\
- & \text { causes eye irritation } \\
- & \text { causes organ damage through long-term or repeated } \\
& \text { exposure }\end{array}$ & $\begin{array}{l}\text { H226 } \\
\text { H302 } \\
\text { H315 } \\
\text { H319 } \\
\text { H372 }\end{array}$ \\
\hline $\begin{array}{c}\mathrm{LiBF}_{4} \\
\text { Lithium Tetrafluoroborate }\end{array}$ & $14283-07-9$ & $\begin{array}{ll}- & \text { harmful if swallowed } \\
\text { - } & \text { causes severe skin burns and eye damage }\end{array}$ & $\begin{array}{l}\text { H302 } \\
\text { H314 }\end{array}$ \\
\hline $\begin{array}{l}\qquad \mathrm{LiClO}_{4} \\
\text { Lithium Perchlorate }\end{array}$ & 7791-03-9 & $\begin{array}{ll}- & \text { may intensify fire } \\
- & \text { oxidizer } \\
- & \text { causes skin irritation } \\
- & \text { causes eye irritation } \\
\text { - } & \text { may cause respiratory tract irritation }\end{array}$ & $\begin{array}{l}\text { H272 } \\
\text { H315 } \\
\text { H319 } \\
\text { H335 }\end{array}$ \\
\hline \multicolumn{4}{|c|}{ Organic Solvents } \\
\hline $\begin{array}{l}\qquad \mathrm{C}_{3} \mathrm{H}_{4} \mathrm{O}_{3} \\
\text { Ethylene carbonate }\end{array}$ & $96-49-1$ & causes severe eye damage & H318 \\
\hline $\begin{array}{c}\mathrm{C}_{4} \mathrm{H}_{6} \mathrm{O}_{3} \\
\text { Propylene carbonate }\end{array}$ & $108-32-7$ & causes eye irritation & H319 \\
\hline $\begin{array}{c}\left(\mathrm{CH}_{3} \mathrm{O}\right)_{2} \mathrm{CO} \\
\text { Dimethyl carbonate }\end{array}$ & $616-38-6$ & flammable liquid substance & $\mathrm{H} 225$ \\
\hline
\end{tabular}


Table 5. Cont.

\begin{tabular}{|c|c|c|c|}
\hline \multirow{2}{*}{ Chemical Compound } & \multirow{2}{*}{ CAS No. } & \multicolumn{2}{|l|}{ Hazard Identification } \\
\hline & & $\mathbf{A} * * *, * * *$ & Category \\
\hline $\begin{array}{l}\qquad \mathrm{C}_{3} \mathrm{H}_{2} \mathrm{O}_{3} \\
\text { Vinylene Carbonate }\end{array}$ & $872-36-6$ & $\begin{array}{ll}- & \text { acute toxicity-orally } \\
- & \text { acute toxicity-dermal } \\
- & \text { causes skin irritation } \\
- & \text { causes severe eye damage } \\
- & \text { causes an allergic skin reaction } \\
- & \text { has a toxic effect on target organs: repeated } \\
\text { - } & \text { exposure-liver, stomach } \\
\text { long-term threat (chronic) to the aquatic environment }\end{array}$ & $\begin{array}{l}\text { H302 } \\
\text { H311 } \\
\text { H315 } \\
\text { H318 } \\
\text { H317 } \\
\text { H373 } \\
\text { H411 }\end{array}$ \\
\hline $\begin{array}{l}\mathrm{C}_{6} \mathrm{H}_{5} \mathrm{~F} \\
\text { Fluorobenzene }\end{array}$ & $462-06-6$ & $\begin{array}{ll}\text { - } & \text { flammable liquid substance } \\
\text { - } & \text { causes eye irritation } \\
\text { - } & \text { long-term threat (chronic) to the aquatic environment }\end{array}$ & $\begin{array}{l}\text { H225 } \\
\text { H319 } \\
\text { H412 }\end{array}$ \\
\hline $\begin{array}{c}\mathrm{LiF}_{2} \mathrm{PO}_{2} \\
\text { Lithium difluorophosphate }\end{array}$ & $24389-25-1$ & $\begin{array}{ll}- & \text { causes skin irritation } \\
- & \text { causes eye irritation } \\
- & \text { has a toxic effect on target organs: single } \\
& \text { exposure-respiratory system }\end{array}$ & $\begin{array}{l}\text { H315 } \\
\text { H319 } \\
\text { H335 }\end{array}$ \\
\hline $\begin{array}{c}\mathrm{F}_{2} \mathrm{LiNO}_{4} \mathrm{~S}_{2} \\
\text { Lithium bis(fluorosulfonyl)imide }\end{array}$ & $171611-11-3$ & - $\quad$ causes severe skin burns and eye damage & H314 \\
\hline $\begin{array}{c}\mathrm{C}_{3} \mathrm{H}_{6} \mathrm{O}_{3} \mathrm{~S} \\
\text { 1,3-Propanesultone }\end{array}$ & $1120-71-4$ & $\begin{array}{ll}- & \text { acute toxicity-orally } \\
- & \text { acute toxicity-dermal } \\
- & \text { causes skin irritation } \\
- & \text { causes severe eye damage } \\
- & \text { carcinogenicity } \\
- & \text { long-term threat (chronic) to the aquatic environment }\end{array}$ & $\begin{array}{l}\text { H302 } \\
\text { H312 } \\
\text { H314 } \\
\text { H318 } \\
\text { H350 } \\
\text { H412 }\end{array}$ \\
\hline $\begin{array}{l}\mathrm{C}_{8} \mathrm{H}_{12} \mathrm{Si} \\
\text { Tetravinylsilane }\end{array}$ & $1112-55-6$ & $\begin{array}{ll}- & \text { flammable liquid substance } \\
- & \text { causes skin irritation } \\
- & \text { causes eye irritation } \\
\text { - } & \text { has a toxic effect on target organs: single } \\
& \text { exposure-respiratory system }\end{array}$ & $\begin{array}{l}\text { H225 } \\
\text { H315 } \\
\text { H319 } \\
\text { H335 }\end{array}$ \\
\hline $\begin{array}{c}\mathrm{C}_{2} \mathrm{H}_{4} \mathrm{O}_{4} \mathrm{~S} \\
\text { 1,3,2-Dioxathiolane 2,2-dioxide }\end{array}$ & $1072-53-3$ & $\begin{array}{l}\text { is not a hazardous substance or mixture according to } \\
\text { Regulation of the European Parliament and the Council (EC) } \\
\text { No. } 1272 / 2008\end{array}$ & - \\
\hline
\end{tabular}

*-Regulation of the European Parliament and the Council (EC) No. 1272/2008 of 16 December 2008 on the classification, labeling and packaging of substances and mixtures, amending and repealing Directives 67/548/EEC and 1999/45/EC and amending Regulation (EC) No. 1907/2006 [13]. **-Safety data sheets of chemical compounds prepared in compliance with Regulation of the European Parliament and of the Council (EC) No. 1907/2006 of 18 December 2006 concerning the registration, evaluation, authorization and restriction of chemicals (REACH), establishing a European Chemicals Agency, amending Directive 1999/45/EC and repealing Council Regulation (EEC) No. 793/93 and Commission Regulation (EC) No. 1488/94 as well as Council Directive 76/769/EEC and Commission Directives 91/155/EEC, 93/67/EEC, 93/105/EC and 2000/21/EC (as amended) [14], available on the websites of companies selling chemical substances [21-33]. ***-ECHA European Chemicals Agency [20].

The current collector materials are made of copper (Cu-CAS 7440-50-8) [34] or aluminum (Al-CAS 7429-90-5) [35] in a metallic form. The binder is polyvinylidene fluoride (PVDF-CAS-24937-79-9) [36]. All these components, according to Regulation of the European Parliament and the Council (EC) No. 1272/2008 are not hazardous substances.

\section{Emission of Hazardous Chemical Substances at the Time of Damage, Leakage and/or Self-Ignition of the Li-Ion Cell}

Special attention must be paid to the emission of hazardous chemical substances at the time of damage, leakage and/or self-ignition of the lithium-ion cell. Nedjalkov et al. [37] present the results of harmful emissions measurements in the artificially induced scenarios of the above events. The authors showed that the composition of the mixture of gases emitted from damaged Li-ion cells is significantly different from their original composition and may be toxic to humans and the environment. The results of these studies are quoted in 
Table 6. Additionally, the authors proposed a solution for the filtration system allowing for significant elimination of harmful compounds from the emitted gases, i.e., a combination of flame-inhibiting textile material and a set of air filters. It can be used in stationary storage systems (even on a large scale) so that the accumulator storage safety can be raised to the next level without changing the accumulator cell structure.

Additionally, attention should be paid to the fact that lithium salts, $\mathrm{LiPF}_{6}$ and $\mathrm{LiBF}_{4}$, which are part of the electrolyte of lithium-ion cells (Table 5), may decompose in contact with water at elevated temperatures. Lithium $\mathrm{LiPF}_{6}$ inorganic salt is characterized by thermal stability up to $107^{\circ} \mathrm{C}$ [38]. Above this temperature, it decomposes according to the Reaction (1).

$$
\mathrm{LiPF}_{6} \rightarrow \mathrm{LiF}+\mathrm{PF}_{5}
$$

At temperature exceeding $70{ }^{\circ} \mathrm{C}$, when in contact with water, LiPF6 reacts according to the Reactions (2)-(5).

$$
\begin{gathered}
\mathrm{LiPF}_{6}+\mathrm{H}_{2} \mathrm{O} \rightarrow \mathrm{LiF}+\mathrm{POF}_{3}+2 \mathrm{HF} \\
\mathrm{POF}_{3}+\mathrm{H}_{2} \mathrm{O} \rightarrow \mathrm{HPO}_{2} \mathrm{~F}_{2}+\mathrm{HF} \\
\mathrm{HPO}_{2} \mathrm{~F}_{2}+\mathrm{H}_{2} \mathrm{O} \rightarrow \mathrm{H}_{2} \mathrm{PO}_{3} \mathrm{~F}+\mathrm{HF} \\
\mathrm{HPO}_{3} \mathrm{~F}+\mathrm{H}_{2} \mathrm{O} \rightarrow \mathrm{H}_{3} \mathrm{PO}_{4}+\mathrm{HF}
\end{gathered}
$$

On the other hand, lithium tetrafluoroborate dissolves in water according to the Reaction (6) [39].

$$
\mathrm{LiBF}_{4}+\mathrm{H}_{2} \mathrm{O} \rightarrow \mathrm{H}_{3} \mathrm{BO}_{3}+\mathrm{HF}+\mathrm{LiF}
$$

\begin{tabular}{|c|c|c|}
\hline \multirow{2}{*}{$\begin{array}{l}\text { Chemical Compound } \\
\text { EMC } \\
\text { ethyl methyl carbonate }\end{array}$} & \multicolumn{2}{|c|}{ Hazard Identification $* * * * * *$} \\
\hline & $\begin{array}{ll}- & \text { causes skin irritation } \\
- & \text { causes eye irritation } \\
- & \text { explosive substance } \\
- & \text { has a toxic effect on target organs }\end{array}$ & H226; H315; H319; H335 \\
\hline $\begin{array}{c}\text { DEC } \\
\text { diethylene carbonate }\end{array}$ & $\begin{array}{ll}- & \text { causes skin irritation } \\
- & \text { causes eye irritation } \\
- & \text { explosive substance } \\
- & \text { has a toxic effect on target organs }\end{array}$ & H226; H315; H319; H335 \\
\hline $\begin{array}{c}\text { EC } \\
\text { ethylene carbonate }\end{array}$ & $\begin{array}{ll}- & \text { causes eye irritation } \\
- & \text { explosive substance } \\
- & \text { has a toxic effect on target organs }\end{array}$ & H315; H319; H335 \\
\hline benzene & $\begin{array}{ll}- & \text { risk connected with inhalation } \\
\text { - } & \text { carcinogenic } \\
\text { - } & \text { causes eye irritatio } \\
\text { - } & \text { mutagenic to reproductive cells }\end{array}$ & $\begin{array}{c}\mathrm{H} 225 ; \mathrm{H} 304 ; \mathrm{H} 315 ; \mathrm{H} 319 \\
\text { H340; H350; H372 }\end{array}$ \\
\hline toluene & $\begin{array}{ll}- & \text { risk connected with inhalation } \\
- & \text { flammable liquid } \\
- & \text { has a harmful effect on the reproductive } \\
- & \text { system } \\
- & \text { causes skin irritation } \\
- & \text { has a toxic effect on target organs }\end{array}$ & $\begin{array}{c}\mathrm{H} 225 ; \mathrm{H} 304 ; \mathrm{H} 315 ; \mathrm{H} 336 \\
\text { H361d; H373 }\end{array}$ \\
\hline
\end{tabular}

The description for all harmful products of these reactions is presented in Table 6 .

Table 6. Composition of the mixture of gases and their hazards following Regulation of the European Parliament and the Council (EC) No. 1272/2008 of 16 December 2008 on the classification, labeling and packaging of substances and mixtures [13] emitted during leakage and/or self-ignition of the lithium-ion cell, based on [37]. 
Table 6. Cont.

\begin{tabular}{|c|c|c|}
\hline Chemical Compound & \multicolumn{2}{|c|}{ Hazard Identification $* * *, * * *$} \\
\hline styrene & $\begin{array}{ll}- & \text { acute toxicity } \\
- & \text { causes skin irritation } \\
- & \text { causes eye irritation } \\
- & \text { flammable liquid } \\
\text { - } & \text { has a toxic effect on target organs }\end{array}$ & $\begin{array}{c}\text { H226; H315; H319; H332 } \\
\text { H361d; H372 }\end{array}$ \\
\hline biphenyl & $\begin{array}{ll}\text { - } & \text { acute and chronic water toxicity } \\
\text { - } & \text { causes eye irritation }\end{array}$ & $\begin{array}{c}\text { H315; H319; H335; H400 } \\
\text { H410 }\end{array}$ \\
\hline acrolein & $\begin{array}{ll}- & \text { acute toxicity } \\
- & \text { acute and chronic water toxicity } \\
- & \text { carcinogenicity } \\
- & \text { flammable liquid } \\
- & \text { corrosive to the respiratory tract } \\
- & \text { damages the eyes } \\
- & \text { mutagenic to reproductive cells } \\
- & \text { causes skin irritation } \\
- & \text { causes an allergic skin reaction }\end{array}$ & $\begin{array}{l}\mathrm{H} 225 ; \mathrm{H} 300 ; \mathrm{H} 300+\mathrm{H} 330 \\
\mathrm{H}-302 ; \mathrm{H} 311 ; \mathrm{H} 314 ; \mathrm{H} 317 \\
\mathrm{H} 318 ; \mathrm{H} 330 ; \mathrm{H} 341 ; \mathrm{H} 351 \\
\mathrm{H} 400 ; \mathrm{H} 410\end{array}$ \\
\hline carbon monoxide & $\begin{array}{ll}- & \text { acute toxicity } \\
\text { - } & \text { flammable gas } \\
\text { - } & \text { has a harmful effect on the reproductive system }\end{array}$ & $\begin{array}{c}\text { H220; H280; H331 H360DM; } \\
\text { H327M }\end{array}$ \\
\hline carbon sulfide & $\begin{array}{ll}- & \text { acute toxicity } \\
\text { - } & \text { causes eye irritation } \\
\text { - } & \text { flammable gas } \\
\text { - } & \text { gas under pressure }\end{array}$ & $\begin{array}{l}\text { H220; H280; H280; H315 } \\
\text { H319; H331; H335 }\end{array}$ \\
\hline Lithium fluoride & $\begin{array}{ll}- & \text { toxic if swallowed } \\
- & \text { causes skin irritation } \\
- & \text { irritating to eyes } \\
- & \text { may cause respiratory irritation }\end{array}$ & H301; H315; H319; H335 \\
\hline Hydrogen fluoride & $\begin{array}{ll}- & \text { fatal if swallowed } \\
- & \text { fatal if swallowed, in contact with skin or if inhaled } \\
- & \text { fatal in contact with skin } \\
- & \text { causes severe skin burns and eye damage } \\
- & \text { causes serious eye damage } \\
- & \text { irritating to eyes- fatal if inhaled }\end{array}$ & $\begin{array}{c}\text { H300; Н310; H330; H310; H314; } \\
\text { H318; H319 }\end{array}$ \\
\hline Phosphoric acid & $\begin{array}{ll} & \text { harmful if swallowed } \\
- & \text { causes severe skin burns and eye damage } \\
- & \text { causes skin irritation } \\
- & \text { causes serious eye damage } \\
\text { - } & \text { irritating to eyes }\end{array}$ & $\begin{array}{c}\text { H290; H302; H314; H315; H318; } \\
\text { H319 }\end{array}$ \\
\hline Boric acid & $\begin{array}{ll}\text { - } & \text { may damage fertility } \\
\text { - } \quad \text { may cause harm to the unborn child }\end{array}$ & H360FD \\
\hline
\end{tabular}

*-Regulation of the European Parliament and the Council (EC) No. 1272/2008 of 16 December 2008 on the classification, labeling and packaging of substances and mixtures, amending and repealing Directives 67/548/EEC and 1999/45/EC and amending Regulation (EC) No. 1907/2006 [13]. **-Safety data sheets of chemical compounds prepared in compliance with Regulation of the European Parliament and of the Council (EC) No. 1907/2006 of 18 December 2006 concerning the registration, evaluation, authorization and restriction of chemicals (REACH), establishing a European Chemicals Agency, amending Directive 1999/45/EC and repealing Council Regulation (EEC) No 793/93 and Commission Regulation (EC) No. 1488/94 as well as Council Directive 76/769/EEC and Commission Directives 91/155/EEC, 93/67/EEC, 93/105/EC and 2000/21/EC (as amended) [14], available on the websites of companies selling chemical substances [40-43]. $* * *$ ECHA European Chemicals Agency [20].

\section{Possibilities of Recycling Waste LiBs}

The growing demand for lithium-ion batteries determines the constantly growing amount of their waste. According to the variety of chemicals included in Li-ion cells, their waste must be properly managed. The recovery of the cell materials, especially the valuable metals contained in battery electrode powder, is the basis of modern waste management systems. Spent Li-ion batteries are successfully processed in specially designed industrial 
installations, and thus their proper management brings an added value, primarily in terms of environmental protection and ecological safety, but is also economically beneficial by reusing raw materials originally contained in processed waste. For the processing of spent Li-ion cells, several different technologies are used based on mechanical methods in combination with pyrometallurgical and/or hydrometallurgical methods. Due to numerous ecological and economic benefits, the most frequent topic of many scientific studies in the field of recycling spent Li-ion cells is the issue of hydrometallurgical recovery of metals (mainly lithium and cobalt) contained in battery powder with the use of acid leaching, where the most common leaching agents are inorganic acids, e.g., sulfuric acid [44], nitric acid [45] and hydrochloric acid [46]. The processes can be additionally supported by a reducing agent, most often hydrogen peroxide $\left(\mathrm{H}_{2} \mathrm{O}_{2}\right)$, which may affect the efficiency of metals recovery, especially cobalt (the presence of the reducer leads to a change in the form of cobalt-from Co(III) to the more soluble Co(II)) [47]. The search for effective solutions that are more environmentally friendly has prompted scientists to identify alternatives in the field of chemical compounds used. As a result, leaching processes with the use of organic acids, which can be leaching and/or reducing agents, are also increasingly investigated [48-50]. It has been shown many times that with appropriate parameters of the leaching process, it is possible to effectively (even completely) separate valuable metals, especially lithium and cobalt. Nevertheless, it should be remembered that the solutions after leaching are polymetallic, and therefore the challenge is to separate them selectively in the subsequent steps. For this purpose, properly designed processes based on methods such as solvent extraction, chemical precipitation or electrochemical deposition can be used [51]. An interesting approach was also proposed by Schiavi P. G. et al. [51]. In these studies, deep eutectic solvent (DES) was used as an alternative, ecological leaching agent to selectively extract target metals, avoiding solvent extraction to separate $\mathrm{Ni}$ and Co.

In addition to metal recovery, an important issue is also the possibility of reusing the anode material, i.e., graphite, and electrolyte from spent batteries, which is also being studied by scientists around the world $[52,53]$.

\section{Conclusions}

Despite the search for ever newer, more technologically advanced solutions, e.g., in the construction and composition of cells, it is lithium-ion batteries and cells that are currently most commonly used to power electric and hybrid vehicles. Therefore, it is necessary to recognize not only the possibilities of their application and development but also to identify potential threats that may significantly impact the environment and human health The article shows that the Li-ion cells are composed of various, often hazardous, chemical substances that are cathode compounds and electrolytes. Improper use of Li-ion cells may result in a high risk of occurrence of factors that can adversely impact the environment and people. Most of the chemical substances used in chemical sources of Li-ion energy cause skin and/or eye irritation are toxic to organs and may cause allergies. A significant number of the compounds used are flammable and have explosive properties. Moreover, during the damage or unsealing of the cell body, a hazardous mixture of gases may be emitted. Therefore, it is crucial to properly store the cells, but also to use them as intended, in compliance with the strictly established guidelines, included for example in the chemical safety data sheets prepared by the battery manufacturer.

Legal restrictions related to the protection of the natural environment are becoming more and more stringent not only in the European Union but also around the world. Therefore, the demand for modern Li-ion batteries will continue to grow, mainly due to the increasing popularity of electric vehicles, which are more ecological than standard cars equipped with internal combustion engines. All cells placed on the retail market, after use, will become waste, which, due to their chemical composition, will pose a threat to the environment. For this reason, to minimize the negative impact of used Li-ion cells, proper management of this type of waste certainly plays a key role. The selective collection is the basis of the current management systems for used batteries and accumulators. Improperly 
discarded battery waste may contaminate the soil and water environment, and thus pose a threat to human health. However, an accurate collection of spent batteries is not enough, as they contain many valuable elements, as shown in this article. These components can be successfully recovered in properly designed technologies and reused, e.g., for the production of new cells, while reducing the consumption of natural resources of many elements, such as lithium or cobalt. Such comprehensive handling of batteries and their waste can significantly minimize the risk of threats to the environment and human health and is part of modern circular economy systems.

Author Contributions: Conceptualization, A.S.-T., W.U., A.J., M.Z. and J.M.; methodology, A.S.-T., W.U., A.J., M.Z. and J.M.; software, A.S.-T., W.U., A.J., M.Z. and J.M.; validation, A.S.-T., W.U., A.J., M.Z. and J.M.; formal analysis, A.S.-T., W.U., A.J., M.Z. and J.M.; investigation, A.S.-T., W.U., A.J., M.Z. and J.M.; resources, A.S.-T., W.U., A.J., M.Z. and J.M.; data curation, A.S.-T., W.U., A.J., M.Z. and J.M.; writing—original draft preparation, A.S.-T., W.U., A.J., M.Z. and J.M.; writing-review and editing, A.S.-T., W.U., A.J., M.Z. and J.M.; visualization, A.S.-T., W.U., A.J., M.Z. and J.M.; supervision, A.S.-T., W.U., A.J., M.Z. and J.M.; project administration, A.S.-T., W.U., A.J., M.Z. and J.M.; funding acquisition, A.S.-T., W.U., A.J., M.Z. and J.M. All authors have read and agreed to the published version of the manuscript.

Funding: This research received no external funding.

Conflicts of Interest: The authors declare no conflict of interest.

\section{References}

1. Marinaro, M.; Bresser, D.; Beyer, E.; Faguy, P.; Hosoi, K.; Li, H.; Sakovica, J.; Amine, K.; Wohlfahrt-Mehrens, M.; Passerini, S. Bringing forward the development of battery cells for automotive applications: Perspective of R\&D activities in China, Japan, the EU and the USA. J. Power Sources 2020, 459. [CrossRef]

2. Tsakalidis, A.; Krause, J.; Julea, A.; Peduzzi, E.; Pisoni, E.; Thiel, C. Electric light commercial vehicles: Are they the sleeping giant of electromobility? Transp. Res. Part D Transp. Environ. 2020, 86. [CrossRef] [PubMed]

3. Bartłomiejczyk, M.; Kołacz, R. The reduction of auxiliaries power demand: The challenge for electromobility in public transportation. J. Clean. Prod. 2020, 252. [CrossRef]

4. Becker, H.; Becker, F.; Abe, R.; Bekhor, S.; Belgiawan, P.F.; Compostella, J.; Frazzoli, E.; Fulton, L.M.; Bicudo, D.G.; Gurumurthy, K.M.; et al. Impact of vehicle automation and electric propulsion on production costs for mobility services worldwide. Transp. Res. Part A Policy Pr. 2020, 138, 105-126. [CrossRef]

5. Deng, Y.; Li, J.; Li, T.; Gao, X.; Yuan, C. Life cycle assessment of lithium sulfur battery for electric vehicles. J. Power Sources 2017, 343, 284-295. [CrossRef]

6. Holden, E.; Banister, D.; Gössling, S.; Gilpin, G.; Linnerud, K. Grand Narratives for sustainable mobility: A conceptual review. Energy Res. Soc. Sci. 2020, 65. [CrossRef]

7. Czerwiński, A. Akumulatory, Baterie, Ogniwa; Wydawnictwo Komunikacji i Łączności: Warszawa, Poland, 2005. (In Polish)

8. Manthiram, A. A reflection on lithium-ion battery cathode chemistry. Nat. Commun. 2020, 11, 1550. [CrossRef] [PubMed]

9. Błachowicz, P. Recycling of Used Second Type Cells-Li-Ion. Materials and Recycling Technologies; Engineering Work; Wrocław University of Science and Technology: Wrocław, Poland, 2019. (In Polish)

10. Juszko, R. Recovery of Cobalt from a Second Type Lithium-Ion Battery (Li-Ion) from Used Portable Computers; Engineering Work; Wrocław University of Science and Technology: Wrocław, Poland, 2019. (In Polish)

11. Battery University. Available online: https://batteryuniversity.com/learn/article/types_of_lithium_ion?fbclid=IwAR3 9COpdhLO0qGVwgHMk3vR9GR9JVgUOkznEFmRAj8ORnWVeZnJjXPKavcw (accessed on 18 May 2021).

12. Yun, L.; Linh, D.; Shui, L.; Peng, X.; Garg, A.; Le, M.L.P.; Asghari, S.; Sandoval, J. Metallurgical and mechanical methods for recycling of lithium-ion battery pack for electric vehicles. Resour. Conserv. Recyc. 2018, 136, 198-208. [CrossRef]

13. EUR-Lex. Regulation (EC) No. 1272/2008 of the European Parliament and of the Council of 16 December 2008 on Classification, Labelling and Packaging of Substances and Mixtures, Amending and Repealing Directives 67/548/EEC and 1999/45/EC, and Amending Regulation (EC) No. 1907/2006. Available online: https:/ / eur-lex.europa.eu/legal-content/EN/TXT/?uri=celex\% 3A32008R1272 (accessed on 1 April 2021).

14. EUR-Lex. Regulation of the European Parliament and of the Council (EC) No. 1907/2006 of 18 December 2006 Concerning the Registration, Evaluation, Authorization and Restriction of Chemicals (REACH), Establishing a European Chemicals Agency, Amending Directive 1999/45/EC and Repealing Council Regulation (EEC) No. 793/93 and Commission Regulation (EC) No. 1488/94 as Well as Council Directive 76/769/EEC and Commission Directives 91/155/EEC, 93/67/EEC, 93/105/EC and 2000/21/EC. Available online: https:/ / eur-lex.europa.eu/legal-content/en/ALL/?uri=CELEX\%3A32006R1907 (accessed on 1 April 2021). 
15. Chemical Substance Safety Data Sheet-LiNi0.33Mn0.33Co0.33O2. Available online: https://www.sigmaaldrich.com/MSDS/ MSDS/DisplayMSDSPage.do? country=PL\&language=pl\&productNumber=761001\&brand=ALDRICH\&PageToGoToURL= https $\% 3 \mathrm{~A} \% 2 \mathrm{~F} \% 2 \mathrm{Fwww}$. sigmaaldrich.com\%2Fcatalog\%2Fproduct $\% 2 F a l d r i c h \% 2 F 761001 \% 3 \mathrm{Flang} \% 3 \mathrm{Dpl}$ (accessed on 1 April 2021).

16. Chemical Substance Safety Data Sheet-LiCoO2. Available online: https://www.sigmaaldrich.com/MSDS/MSDS/ DisplayMSDSPage.do country=PL\&language $=$ pl\&productNumber $=442704 \&$ brand $=$ ALDRICH\&PageToGoToURL=https $\%$ 3A \%2F\%2Fwww.sigmaaldrich.com\%2Fcatalog\%2Fproduct\%2Faldrich\%2F442704\%3Flang\%3Dpl (accessed on 1 April 2021).

17. Chemical Substance Safety Data Sheet-LiMn2O4. Available online: https://www.sigmaaldrich.com/MSDS/MSDS/ DisplayMSDSPage.do? country=PL\&language=pl\&productNumber=725129\&brand=ALDRICH\&PageToGoToURL=https $\%$ 3A \%2F\%2Fwww.sigmaaldrich.com\%2Fcatalog\%2Fproduct \%2Faldrich\%2F725129\%3Flang\%3Dpl (accessed on 1 April 2021).

18. Chemical Substance Safety Data Sheet-LiFePO4. Available online: https://www.sigmaaldrich.com/MSDS/MSDS/ DisplayMSDSPage.do? country=PL\&language=pl\&productNumber=759546\&brand=ALDRICH\&PageToGoToURL=https $\%$

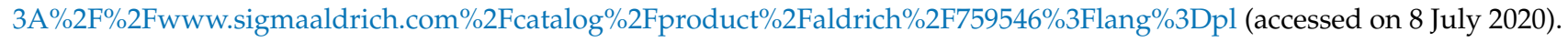

19. Chemical Substance Safety Data Sheet-Graphite. Available online: https://www.merckmillipore.com/PL/pl/product/msds / MDA_CHEM-104206? Origin=PDP (accessed on 1 April 2021).

20. ECHA European Chemicals Agency. Available online: https://echa.europa.eu/pl/information-on-chemicals (accessed on 1 April 2021).

21. Chemical Substance Safety Data Sheet-LiClO4. Available online: https://www.sigmaaldrich.com/MSDS/MSDS/DisplayMSDSPage. do? country=PL\&language =pl\&productNumber=634565\&brand=ALDRICH\&PageToGoToURL=https $\% 3 \mathrm{~A} \% 2 \mathrm{~F} \% 2 \mathrm{Fwww}$. sigmaaldrich.com\%2Fcatalog\%2Fproduct\%2Faldrich\%2F634565\%3Flang\%3Dpl (accessed on 1 April 2021).

22. Chemical Substance Safety Data Sheet-LiBF4. Available online: https://www.sigmaaldrich.com/MSDS/MSDS/DisplayMSDSPage. do? country=PL\&language=pl\&productNumber=244767\&brand=ALDRICH\&PageToGoToURL=https $\% 3 \mathrm{~A} \% 2 \mathrm{~F} \% 2 \mathrm{Fwww}$. sigmaaldrich.com\%2Fcatalog\%2Fproduct\%2Faldrich\%2F244767\%3Flang\%3Dpl (accessed on 1 April 2021).

23. Chemical Substance Safety Data Sheet-LiPF6. Available online: https:/ /www.sigmaaldrich.com/MSDS/MSDS/DisplayMSDSPage. do? country=PL\&language=pl\&productNumber=746746\&brand=ALDRICH\&PageToGoToURL=https $\% 3 \mathrm{~A} \% 2 \mathrm{~F} \% 2 \mathrm{Fwww}$. sigmaaldrich.com\%2Fcatalog\%2Fproduct\%2Faldrich\%2F746746\%3Flang\%3Dpl (accessed on 1 April 2021).

24. Chemical Substance Safety Data Sheet-C3H4O3. Available online: https://www.sigmaaldrich.com/MSDS/MSDS/ DisplayMSDSPage.do? country=PL\&language=EN-generic\&productNumber=107360\&brand=ALDRICH\&PageToGoToURL= https \%3A\%2F\%2Fwww.sigmaaldrich.com\%2Fcatalog\%2Fproduct\%2Faldrich\%2F107360\%3Flang\%3Dpl (accessed on 1 April 2021).

25. Chemical Substance Safety Data Sheet-C4H6O3. Available online: https://www.merckmillipore.com/PL/pl/product/Propylenecarbonate,MDA_CHEM-807051 (accessed on 1 April 2021).

26. Chemical Substance Safety Data Sheet-(CH3O)2CO. Available online: https://www.merckmillipore.com/PL/pl/product/msds/ MDA_CHEM-803525?Origin=PDP (accessed on 1 April 2021).

27. Chemical Substance Safety Data Sheet-C3H2O3. Available online: https://www.sigmaaldrich.com/MSDS/MSDS/ DisplayMSDSPage.do? country=PL\&language=pl\&productNumber=V2607\&brand=ALDRICH\&PageToGoToURL=https $\%$ 3A \%2F\%2Fwww.sigmaaldrich.com\%2Fcatalog\%2Fsearch\%3Fterm\%3D872-36-6\%26interface\%3DCAS\%2520No.\%26N\%3D0 \%26mode\%3Dpartialmax\%26lang\%3Dpl\%26region\%3DPL\%26focus\%3Dproduct (accessed on 1 April 2021).

28. Chemical Substance Safety Data Sheet-C6H5F. Available online: https:/ / www.sigmaaldrich.com/MSDS/MSDS/DisplayMSDSPage. do? country=PL\&language =pl\&productNumber=F6001\&brand=ALDRICH\&PageToGoToURL=https \%3A \%2F\%2Fwww. sigmaaldrich.com\%2Fcatalog\%2Fproduct\%2Faldrich\%2Ff6001\%3Flang\%3Dpl (accessed on 1 April 2021).

29. Chemical Substance Safety Data Sheet-C3H6O3S. Available online: https://www.sigmaaldrich.com/MSDS/MSDS/ DisplayMSDSPage.do? country=PL\&language=pl\&productNumber=471690\&brand=ALDRICH\&PageToGoToURL=https $\%$ 3A\%2F\%2Fwww.sigmaaldrich.com\%2Fcatalog\%2Fproduct $\% 2 F a l d r i c h \% 2 F 471690 \% 3 F l a n g \% 3 D p l$ (accessed on 1 April 2021).

30. Chemical Substance Safety Data Sheet-LiF2PO2. Available online: https://www.warshel.com/wp-content/uploads/20 19/11/MSDS-of-LiPO2F2Lithium-phosphorodifluoridate-CAS-24389-25-1.pdf?fbclid=IwAR2jVHkQyP6lv4YgGIylqKx4 OkgOWHGlHJpdCapP7HOC9kTveqpwkDiv-BE (accessed on 1 April 2021).

31. Chemical Substance Safety Data Sheet-Lithium. Bis(fluorosulfonyl)imide. Available online: https://www.chemicalbook.com/ ChemicalProductProperty_EN_CB82604260.htm (accessed on 1 April 2021).

32. Chemical Substance Safety Data Sheet-Tetrawinylosilan. Available online: https://www.sigmaaldrich.com/MSDS/MSDS/ DisplayMSDSPage.do? country=PL\&language=pl\&productNumber=318256\&brand=ALDRICH\&PageToGoToURL=https $\%$ 3A\%2F\%2Fwww.sigmaaldrich.com\%2Fcatalog\%2Fsearch\%3Fterm\%3D1112-55-6\%26interface \%3DCAS\%2520No.\%26N\%3D0 \%26mode\%3Dpartialmax\%26lang\%3Dpl\%26region\%3DPL\%26focus\%3Dproduct (accessed on 1 April 2021).

33. Chemical Substance Safety Data Sheet-1,3-Propanosulton. Available online: https://www.sigmaaldrich.com/MSDS/MSDS/ DisplayMSDSPage.do? country=PL\&language=pl\&productNumber=P50706\&brand=ALDRICH\&PageToGoToURL=https $\% 3 A \%$ 2F\%2Fwww.sigmaaldrich.com\%2Fcatalog\%2Fproduct\%2Faldrich\%2Fp50706\%3Flang\%3Dpl (accessed on 1 April 2021).

34. Chemical Substance Safety Data Sheet-Cu. Available online: https://chempur.pl/pliki/karty_charakterystyk/miedz_metal_ wiory.pdf (accessed on 1 April 2021).

35. Chemical Substance Safety Data Sheet-Al. Available online: http://www.poch.com.pl/1/wysw/msds_clp.php?A=5497f84d5a9 8f6430001 (accessed on 1 April 2021). 
36. Chemical Substance Safety Data Sheet-Polyvinylidene Fluoride. Available online: https://www.sigmaaldrich.com/MSDS/MSDS/ DisplayMSDSPage.do? country=PL\&language=pl\&productNumber=347078\&brand=ALDRICH\&PageToGoToURL=https $\% 3 \mathrm{~A} \%$ 2F\%2Fwww.sigmaaldrich.com\%2Fcatalog\%2Fproduct\%2Faldrich\%2F347078\%3Flang\%3Dpl (accessed on 1 April 2021).

37. Nedjalkov, A.; Meyer, J.; Köhring, M.; Doering, A.; Angelmahr, M.; Dahle, S.; Sander, A.; Fischer, A.; Schade, W. Toxic Gas Emissions from Damaged Lithium Ion Batteries-Analysis and Safety Enhancement Solution. Batteries 2016, 2, 5. [CrossRef]

38. Srivastava, A.K.; Misra, N. Designing new electrolytic salts for Lithium Ion Batteries using superhalogen anions. Polyhedron 2016, 117, 422-426. [CrossRef]

39. Liu, Z.; Chai, J.; Xu, G.; Wang, Q.; Cui, G. Functional lithium borate salts and their potential application in high performance lithium batteries. Coord. Chem. Rev. 2015, 292, 56-73. [CrossRef]

40. Chemical Substance Safety Data Sheet-LiF. Available online: https://www.sigmaaldrich.com/MSDS/MSDS/DisplayMSDSPage. do? country=PL\&language $=$ pl\&productNumber $=449903 \&$ brand $=$ ALDRICH\&PageToGoToURL=https $\% 3 \mathrm{~A} \% 2 \mathrm{~F} \% 2 \mathrm{Fwww}$. sigmaaldrich.com\%2Fcatalog\%2Fproduct\%2Faldrich\%2F449903\%3Flang\%3Dpl (accessed on 18 May 2021).

41. Chemical Substance Safety Data Sheet-HF. Available online: https://www.sigmaaldrich.com/MSDS/MSDS/PleaseWaitMSDSPage. do?language $=\&$ country=PL\&brand=SIGALD\&productNumber=339261\&PageToGoToURL=https: / / www.sigmaaldrich.com / catalog/product/sigald /339261?lang=pl\&region=PL\&cm_sp=Insite-_-caSrpResults_srpRecs_srpModel_hf-_-srpRecs3-1 (accessed on 18 May 2021).

42. Chemical Substance Safety Data Sheet-H3PO4. Available online: https://www.sigmaaldrich.com/MSDS/MSDS/PleaseWaitMSDSPage. do?language=\&country=PL\&brand=SIGALD\&productNumber=695017\&PageToGoToURL=https: / / www.sigmaaldrich.com/catalog / product/sigald/695017?lang=pl\&region=PL\&cm_sp=Insite-_-caSrpResults_srpRecs_srpModel_h3po4*-_-srpRecs3-1 (accessed on 18 May 2021).

43. Chemical Substance Safety Data Sheet-H3BO3. Available online: https://www.sigmaaldrich.com/MSDS/MSDS/DisplayMSDSPage. do? country=PL\&language=pl\&productNumber=B6768\&brand=SIGMA\&PageToGoToURL=https $\% 3 \mathrm{~A} \% 2 \mathrm{~F} \% 2 \mathrm{Fwww}$. sigmaaldrich . com\%2Fcatalog\%2Fproduct \%2Fsigma\%2Fb6768\%3Flang\%3Dpl (accessed on 18 May 2021).

44. Urbańska, W.; Osial, M. Investigation of the Physico-Chemical Properties of the Products Obtained after Mixed Organic-Inorganic Leaching of Spent Li-Ion Batteries. Energies 2020, 13, 6732. [CrossRef]

45. Fajaryanto, R.; Nurqomariah, A.; Silvia. Acid leaching and kinetics study of cobalt recovery from spent lithium-ion batteries with nitric acid. In Proceedings of the 3rd International Tropical Renewable Energy Conference "Sustainable Development of Tropical Renewable Energy" (i-TREC 2018), Bali, Indonesia, 6-8 September 2018; Volume 67. [CrossRef]

46. Barik, S.P.; Prabaharan, G.; Kumar, L. Leaching and separation of Co and Mn from electrode materials of spent lithium-ion batteries using hydrochloric acid: Laboratory and pilot scale study. J. Clean. Prod. 2017, 147, 37-43. [CrossRef]

47. Lee, C.K.; Rhee, K.I. Reductive leaching of cathodic active materials from lithium ion battery wastes. Hydrometallurgy 2003, 68, 5-10. [CrossRef]

48. Golmohammadzadeh, R.; Faraji, F.; Rashchi, F. Recovery of lithium and cobalt from spent lithium ion batteries (LIBs) using organic acid as leachant reagents: A review. Res. Conserv. Rec. 2019, 136, 418-435. [CrossRef]

49. Musariri, M.; Akdogan, G.; Dorfling, C.; Bradshaw, S. Evaluating organic acids as alternative leaching reagents for metal recovery from lithium ion batteries. Miner. Eng. 2019, 137, 108-117. [CrossRef]

50. Demarco, J.O.; Cadore, J.S.; de Oliveira, F.S.; Tanabe, E.H.; Bertuol, D.A. Recovery of metals from spent lithium-ion batteries using organic acids. Hydrometallurgy 2019, 190. [CrossRef]

51. Schiavi, P.G.; Altmari, P.; Branchi, M.; Zanoni, R.; Simonetti, G.; Navarra, M.A.; Pagnanelli, F. Selective recovery of cobalt from mixed lithium ion battery wastes using deep eutectic solvent. Chem. Eng. J. 2021, 417. [CrossRef]

52. Fujita, T.; Chen, H.; Wang, K.; He, C.; Wang, Y.; Dodbiba, G.; Wei, Y. Reduction, reuse and recycle of spent Li-ion batteries for automobiles: A review. Int. J. Miner. Metall. Mater. 2021, 28, 179. [CrossRef]

53. Schiavi, P.G.; Altimari, P.; Zanoni, R.; Pagnanelli, F. Full recycyling of spent lithium ion batteries with production of core-shell nanowires//exfoliated graphite asymmetric supercapacitor. J. Energy Chem. 2021, 58, 336-344. [CrossRef] 